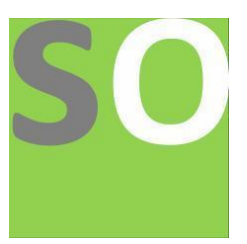

Article title: A Study Of Water Quality In The Amaravathi Area, Guntur Dist, Andhra Pradesh, India Authors: Srinivasa Rao p [1], sumanth kommathoti[2], Kamal Teja M[3]

Affiliations: Research scholor Dept of civil engineering JNTU Anthapur[1], Department of civil engineering Dhanekula Inst of Engg \& Tech[2]

Orcid ids: 0000-0001-9984-4884[2]

Contact e-mail: sumanthchintu5@gmail.com

License information: This work has been published open access under Creative Commons Attribution License http://creativecommons.org/licenses/by/4.0/, which permits unrestricted use, distribution, and reproduction in any medium, provided the original work is properly cited. Conditions, terms of use and publishing policy can be found at https://www.scienceopen.com/.

Preprint statement: This article is a preprint and has not been peer-reviewed, under consideration and submitted to ScienceOpen Preprints for open peer review.

DOI: 10.14293/S2199-1006.1.SOR-.PPMP9XP.v1

Preprint first posted online: 27 May 2020

Keywords: $\mathrm{pH}$, Turbidity, Chlorides, Hardness, Dissolved Oxygen (DO), Biochemical Oxygen Demand (BOD), BIS, WHO, AMARAVATHI. 


\title{
A STUDY OF WATER QUALITY IN AMARAVATHI AREA, GUNTUR DIST, ANDHRA PRADESH.
}

\author{
P.SRINIVASA RAO' ${ }^{1}$, K.SUMANTH ${ }^{2}$,M.KAMALTEJA ${ }^{3}$ D.RAJESH ${ }^{4}$, J.RAJ KUMAR $^{5}$ \\ ${ }^{1}$ Research scholar Department of civil engineering JNTU ANANTAPUR, ANANTAPURAMU ANDHRA PRADESH, INDIA \\ 2,3,4,5 Undergraduate students, Department of Civil Engineering, DHANEKULA INSTITUTE OF ENGINEERING \&TECHNOLOGY ANDHRA \\ PRADESH, INDIA
}

\begin{abstract}
Water is the important for everyone for land and regulating the climate. It is one of the most important compounds that profoundly influence life. The quality of water usually described according to its physical and chemical characteristics. The quality of water is studied in the villages of AMARAVATHI, Andhra Pradesh, India. The water samples from ten locations within the area of the Amaravathi region are collected with monthly variations for three month and analysed for their suitability with respect to drinking, irrigation. The results are compared with the respective BIS codes and Indian standards coads analysed using different approaches (a) National Sanitation Foundation Water Quality Index (NSFWQI) (b) Nemerow's pollution index method . However, the overall ground water quality is suitable for irrigation purposes, though a few parameters showed high values at few locations.. Parameters that are tested include temperature ,pH, Hardness, Acidity, Alkalinity ,turbidity ,chlorides ,DO,BOD and based on the quality treatment plant will also be designed. The water quality is ranked as Excellent Good Poor to Very Poor in the study region based on test results.
\end{abstract}

INDEX WORDS: pH, Turbidity, Chlorides, Hardness, Dissolved Oxygen (DO), Biochemical Oxygen Demand (BOD), BIS, WHO, AMARAVATHI.

Introduction Water covers $71 \%$ of earth surface. In that almost $96.5 \%$ is salt water and the remaining $3.5 \%$ is fresh water. In that $3.5 \%$ also $2.15 \%$ is in the form of Glaciers. Only $0.3 \%$ is usable by the humans for their survival and for other activities. Water as extra ordinary substance exist in three states as gasses, Liquid proved important for survivability of life [1]. That usable fresh water is existing above and below the Ground, they are surface and subsurface sources of water. Sub-surface sources are the ground water sources which contain $0.61 \%$ of water and the surface sources are rivers, lakes and streams. River water quality is an important for each state holders as it effects human uses as well as plant and human life [2]. Water plays an important role in world's economy. Approximately $70 \%$ of the freshwater used by humans goes to agriculture. Fresh water sources are in the form of rivers are very much essential [3]. Fishing in salt water and fresh water bodies is a major source of food for many parts of the world, much of the long distance trade of commodities and manufactured products is transported by boats through seas ,rivers, lakes, and canals .large quantities of water, ice and stream used for cooling and heating in industry and homes.water is an excellent solvent for wide variety of chemical substances, as such it is widely used in industrial processes, and in cooking and washing. water is also central to many sports and other forms of entertainments, such as swimming, pleasure boating, boat racing,surfing, sport fishing, and diving. Water is one of the most important natural resources that is essential for the sustenance of life on our planet earth. To preserve the water resources against pollution the implantation of stringent rules and guide lines are needed to preserve resources for future generations [4]. Apart from human domestic consumption, water is highly used in agriculture, commercial, recreational, navigational, industrial and so on.

It is required to use proper quality of water used for drinking and irrigation purposes. Usage of quality less water for drinking will adversely affect human health. Regular monitoring and effective management strategy to be taken to protect water bodies for further pollution [5].In developing countries like India most of the population use untreated groundwater for various purposes, as they do not have access to good quality of water. The suitability of water drinking depends on various constituents such as suspended particles and dissolved inorganic ,organic, radiological and biological constituents .the bureau of Indian standards (BIS 2003) and the world health organization (WHO 2006) have prescribed maximum permissible limits for various dissolved ions in water used for human intake.Researchers around the world have studied the quality of water based on these standards .all biological reactions occur in water and it is the integrated system of biological metabolic reactions in an aqueous solution that is essential for the maintenance of life.Most human activities involve the use of water in one way or other .it may 
be noted that humans early habitation and civilization sprang up along the banks of rivers. Fresh water is essential for human life and its quality is a matter of global concerned[6].

The water pollution control strategies largely depend on the characteristics of water quality. Drinking water sources are under increasing threat for contamination [11]. To obtain precise and appropriate information pertaining the quality characteristics of water is to assess various quality parameters i.e. physical, chemical and biological through the analysis of the water sample collected from the identified water resource. The assessment of water quality may lead to the development of some useful tools to keep watch on the quality of such priceless water resources and to retain their excellence for various beneficial uses. Hence, water quality assessment is important for strategic management plans.

Water borne pathogens can enter human body though intact or compromised skin, inhalation, ingestion, aspiration, or by direct contact with mucosa of the eye, ear ,nose, mouth and genitals ,and cause disease. 50\% wastes com industries are directly released to rivers and seas [12]. Besides failure of potable water systems, which usually contribute to the greatest number of outbreaks of waterborne diseases common outdoor recreational activities such as swimming ,boating, bathing, camping and hiking, all place humans at risk of waterborne diseases from ingestion or direct contact with contaminated water [13]. A risk analysis approach is required for overcoming the problems with water borne diseases and water quality monitoring. while this could be achieved relatively easily with respect to chemical contaminants and standards could be setup.

The problem of the quality of water resources in general, and groundwater resources in particular, is becoming increasingly important in any nation. Although water is the most frequently occurring substance on earth, lack of clean water is more prominent in the developing areas. Groundwater is the main source of water supply throughout the world. Due to increasing demand of world population, and increasing urban needs, ground water is being extracted for irrigation, construction works, and industries, urban and rural households day by day. During dry season the withdrawal of groundwater for irrigation purpose is very difficult. lowering the water table in the aquifer and also changing the chemical composition of water quality. After the bifurcation of Andhra Pradesh, water demand is increased in the AP Capital Regional Developmental Agency (AP CRDA) area in various forms such as housing, new constructions, population migrations, infrastructural facility creation etc. besides continuing with agricultural practices. The water availability in terms of quantity and quality needs to be studied in this perspective. The water quality, particularly ground water quality, is an important parameter because of severe exploitation of groundwater in the region for the different needs. Several studies are reported for the study of ground water quality for drinking purpose in this region. In the study area groundwater sample and surface water samples were collected in AMARAVATHI reagion. Ten villages/towns ( Yerrabalam, Krishnayapalem, ZPHS Mandadam, Velagapudi, Rayapudi, Thullur, Amaravathi, SRM unvesity, Lingaya palem, dondapadu. ) are identified within the amaravathi region limits. These samples are assessed on the bases of various qualitative parameters. The considered water quality parameters are Ph, Electrical conductivity, Hardness, Chlorides, D.O, BOD, Colour, Taste, Odour, Alkalinity, Turbidity, TDS.

STUDY AREA AMARAVATHI is a town located on the banks of Krishna River, in Guntur district of the Indian state of Andhra Pradesh. It is the headquarters of AMARAVATHI mandal, and forms part of the Andhra Pradesh Capital Region. It is situated at $16.579444^{\circ} \mathrm{N} 80.311111^{\circ} \mathrm{E}$. It is spread over an area of 1,524 ha $(3,770$ acres) it is $18.9 \mathrm{~km}$ from vijayawada and pin code is 522020 and postal head office is AMARAVATHI Telugu is the local language here. Total population of AMARAVATHI is 13,400 with 3,316 households. The total population constitute, 6,432 males and 6,958 females — a sex ratio of 1,082 females per 1,000 males. 1,321 children are in the age group of 0-6 years, of which 647 are boys and 674 are girls — a ratio of 1,042 per 1,000. The average literacy rate stands at $71.34 \%$ with 8,617 literates, higher than the state average of $67.41 \%$. AMARAVATHI'S economy is based on Agriculture. 


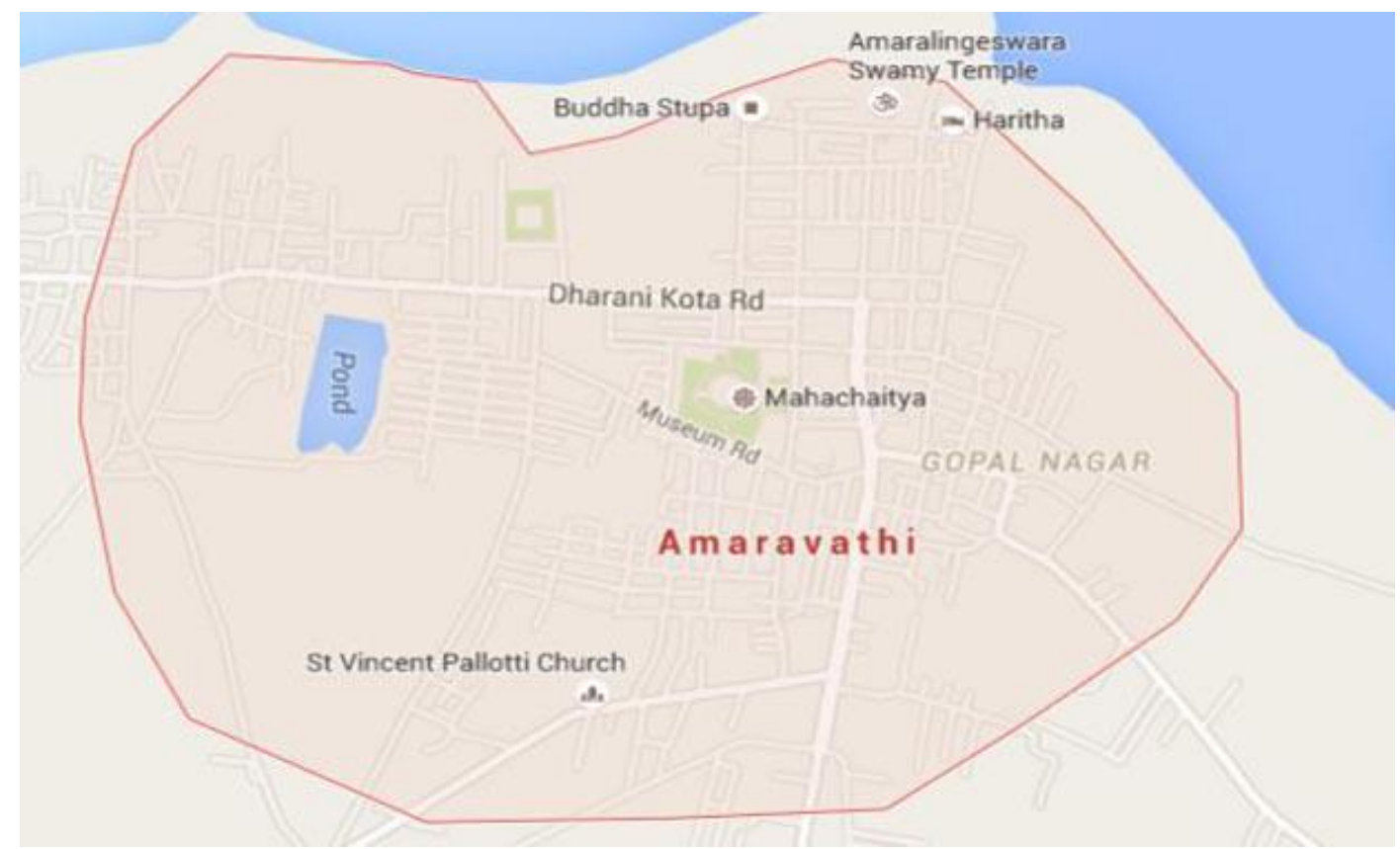

Figure 1 Map of study area

\section{METHODOLOGY}

Raw water sampling(collection) From the study area for analysis of the sampled water to determine physic-chemical parameters such as pH, Electrical conductivity, Hardness, Chlorides, D.O, BOD, Colour, Taste, Odour, Alkalinity, Turbidity, TDS.. The observed results are calculated further for comparison of the results with water quality index and with Nemerow's pollution index method for rating the quality of the water.

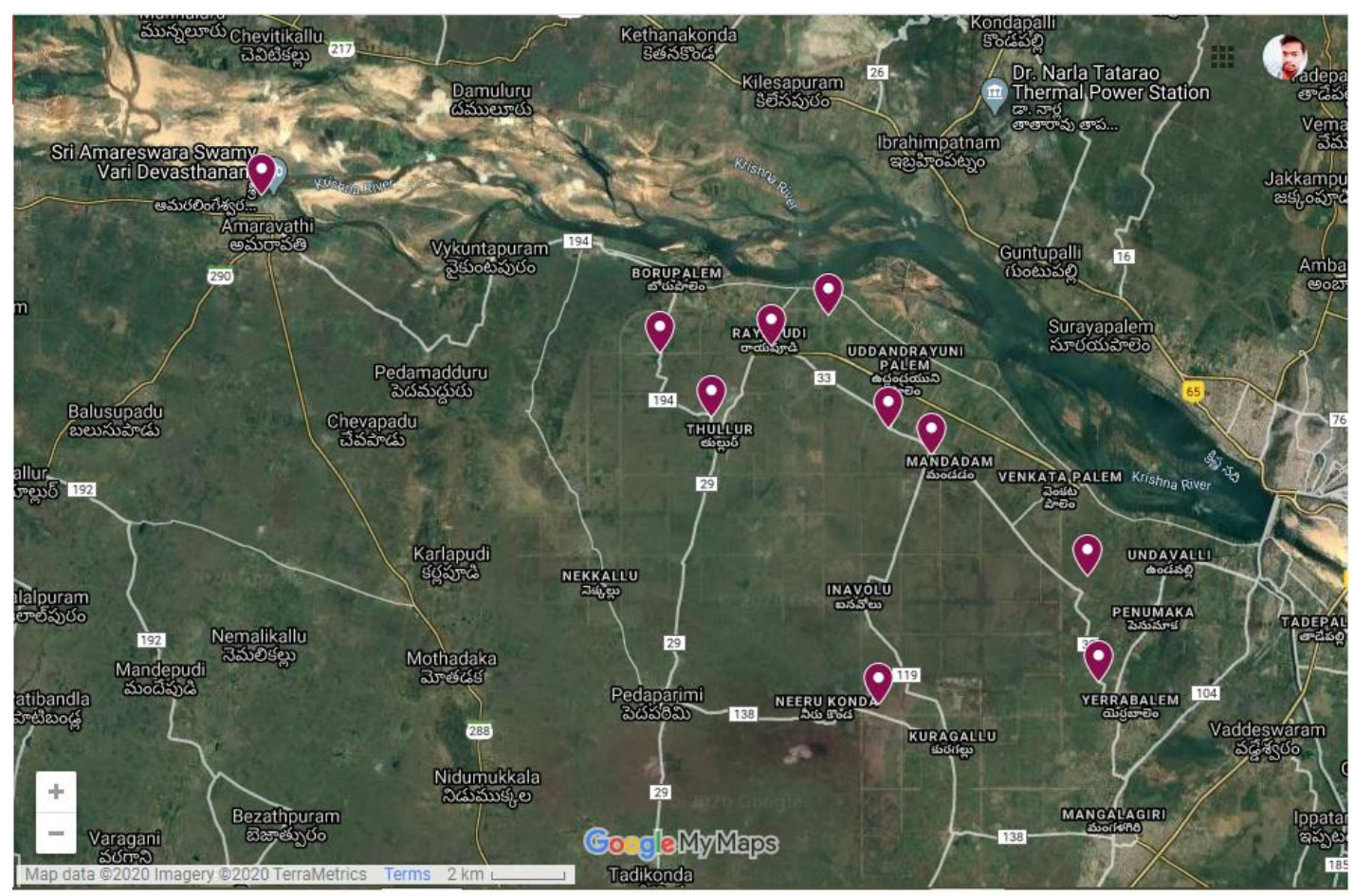

Figure 2 map of the location sites 


\begin{tabular}{|c|c|c|c|}
\hline stations & & & \\
\hline 1 & YERRABALAM & $16^{\circ} 477160^{\prime}$ & $80^{\circ} 562526^{\prime}$ \\
\hline 2 & KRISHANAYAPALEM & $16^{\circ} 492250^{\prime}$ & $80^{\circ} 559687^{\prime}$ \\
\hline 3 & MANDADAM & $16^{\circ} 520820^{\prime}$ & $80^{\circ} 521301^{\prime}$ \\
\hline 4 & VELAGAPUDI & $16^{\circ} 527110^{\prime}$ & $80^{\circ} 510661^{\prime}$ \\
\hline 5 & RAYAPUDI & $16^{\circ} 546268^{\prime}$ & $80^{\circ} 481692^{\prime}$ \\
\hline 6 & THULLUR & $16^{\circ} 529418^{\prime}$ & $80^{\circ} 466993^{\prime}$ \\
\hline 7 & AMARAVATHI & $16^{\circ} 581778^{\prime}$ & $80^{\circ} 355939^{\prime}$ \\
\hline 8 & SRM UNVERSITY & $16^{\circ} 461831^{\prime}$ & $80^{\circ} 508211^{\prime}$ \\
\hline 9 & LINGAYA PALEM & $16^{\circ} 553559^{\prime}$ & $80^{\circ} 495817^{\prime}$ \\
\hline 10 & DONDAPADU & $16^{\circ} 272727^{\prime}$ & $81^{\circ} 022114^{\prime}$ \\
\hline
\end{tabular}

Table1 showing sampling location along with names and latitude and longitude

From table1 the calculation of water quality index was done by National Sanitation Foundation Water Quality Index (NSFWQI).

\subsection{National Sanitation Foundation Water Quality Index (NSFWQI)}

Water quality index developed by Brown et al. using Delphi method was done by selecting parameters rigorously, developing a common scale and assigning weights to the parameters. National Sanitation Foundation (NSF) supported this index so also called as NSFWQI. It has been mentioned in many papers because it's the most comprehensive work [10][38 ]. Based on experts opinion rating curves are developed to attribute values for variation in the level of water quality caused by different levels of each of the selected parameters. Computing a water quality index is possible by established rating curves and associated weights, such as Additive index

$\mathrm{WQI}=\sum_{\mathrm{i}=1}^{\mathrm{n}} \mathrm{Qiwi}$

\section{$\mathbf{W i}=\mathbf{k} / \mathbf{S i}$}

$\mathrm{K}=\sum_{\mathrm{i}=\mathbf{1}}^{\mathrm{n}} \mathrm{Wi}=\mathbf{1}($ General $)$

$\mathbf{Q} \mathbf{i}=(\mathbf{V a}-\mathbf{V i}) /(\mathbf{S i}-\mathbf{V i})$

Where

$$
\sum_{i=1}^{n} W i=1
$$

\section{Wi $=$ Weighting factor}

$Q i=$ is the rating value of parameter

I and $n=$ Number of sub-indices.

After calculation of water quality index the water catagiry is marked with reference of table2

\begin{tabular}{|c|c|c|}
\hline SI.NO & Water Quality index & Status \\
\hline 1 & $0-25$ & Excellent \\
\hline 2 & $26-50$ & Good \\
\hline 3 & $51-75$ & Fair \\
\hline
\end{tabular}




\begin{tabular}{|c|c|c|}
\hline 4 & 76100 & Poor \\
\hline 5 & $101-150$ & Very poor \\
\hline 6 & Above 150 & $\begin{array}{c}\text { Unstable for drinking } \\
\text { (U.F.D) }\end{array}$ \\
\hline
\end{tabular}

Table 2 Status of Water Quality Based on WQI

Calculation water quality based on Nemerow's Pollution index method

Nemerow's pollution index (NPI) is an easy pollution index that introduced by Neme. Besides models, several water quality indices have been developed and used time to time. Water quality indices are generally used as a tool to convert a large data set into a much reduced and informative form so that underlined facts about the characteristics of the sample may be extracted. Nemerow's pollution index is a water quality index. Avery simplified pollution index was introduced by Nemerow, which is generally known as Nemerow's pollution index (NPI). It may be mathematically expressed as

$\mathrm{NPI}=\mathrm{Ci} / \mathrm{Li}$

Where

$\mathrm{Ci}=$ observed concentration of $\mathrm{i}$ parameter

$\mathrm{Li}=$ permissible limit of $\mathrm{i}$ parameter

In above expressions unit of $\mathrm{Ci}$ and $\mathrm{Li}$ should be identical. Each value of NPI shows the relative pollution contributed by single parameter. NPI values exceeding 1.0 indicate the presence of impurity in water and hence require some treatment prior to use.

\begin{tabular}{|l|l|}
\hline Nemerow's Pollution Index (NPI): (observed valve/ standard value) & Status \\
\hline Less than one & It is not a pollutant \\
\hline Greater than one & It is a pollutant \\
\hline
\end{tabular}

Table 3 showing the Water Quality based on NPI

\begin{tabular}{|l|l|}
\hline Analysis & Method/ Instrument \\
\hline $\mathrm{pH}$ & Digital pH Meter \\
\hline Electrical Conductivity & Digital Conductivity Meter \\
\hline Total Dissolved Solids & Using TDS PEN \\
\hline Total Hardness & EDTA Titrimetry \\
\hline Temparary Hardness & EDTA Titrimetry \\
\hline Permanent Hardness & Indirect method ( Total Hardness - Temparary Hardness ) \\
\hline
\end{tabular}




\begin{tabular}{|l|l|}
\hline Chlorides & Mohr's - Titrimetry \\
\hline DO & Winkler method \\
\hline BOD & Iodometric (Titrimetric) \\
\hline COD & Titrimetric \\
\hline Colour & Physical Observation \\
\hline Taste & Physical Observation \\
\hline Odour & Physical Observation \\
\hline Turbidity & Digital Turbidity Meter \\
\hline
\end{tabular}

Table 3.1 showing Analytical methods adopted for Physico-chemical analysis

\begin{tabular}{|c|c|}
\hline PARAMETER STUDIED & REQUIRED SOLUTIONS \\
\hline $\begin{array}{c}\text { Dissoloved oxygen, } \\
\text { BOD }\end{array}$ & $\begin{array}{l}\text { 1. MnSo4 } \\
\text { 2. Alkail-iodide-Azide reagent } \\
\text { 3. Starch indicator } \\
\text { 4. } 0.025 \mathrm{~N} \text { Hypo solution (Na2S2O3) } \\
\text { 5. Conc } \mathrm{H} 2 \mathrm{So} 4\end{array}$ \\
\hline COD & $\begin{array}{c}\text { 1.0.025N K2Cr2O7+SULPHARIC } \\
\text { 2.ACID(H2SO4) } \\
\text { 3.H2SO4 With AgSO4 } \\
\text { 4.Ferroin Indicator } \\
\text { 5.Mohr's Salt solution }\end{array}$ \\
\hline Alkalinity & $\begin{array}{l}\text { 1.0.02N Standard Sulphuric Acid } \\
\text { 2.Phenolphthalein indicator } \\
\text { 3.Methyl Orange indicator } \\
\text { 4.Co2 Free distilled water } \\
\text { 5.Sodium thiosulphate } 0.1 \mathrm{~N}\end{array}$ \\
\hline ACIDITY & 1.Standard sodium hydroxide $0.02 \mathrm{~N}$ \\
\hline
\end{tabular}




\begin{tabular}{|c|c|}
\hline & $\begin{array}{l}\text { 2.Phenolphthalein indicator } \\
\text { 3.Methyl Orange indicator } \\
\text { 4.Sodium thiosulphate } 0.1 \mathrm{~N} \\
\text { 5.Co2 Free distilled water }\end{array}$ \\
\hline CHLORIDES & $\begin{array}{l}\text { 1.Standard } \mathrm{NaCl} \text { solution } \\
\text { 2.Potassium chromate indicator } \\
\text { 3.Standard silver nitrate } 0.0141 \mathrm{~N} \\
\text { 4.Chlorides free distilled water }\end{array}$ \\
\hline HAREDNESS & $\begin{array}{c}\text { 1.Buffer solution } \\
\text { 2.EBT indicator } \\
\text { 3.Standard EDTA solution } 0.01 \mathrm{M} \\
\text { 4.Standard Calcium solution } \\
\text { 5.Meuroxide Indicator } \\
\text { 6.Sodium hydroxide } 2 \mathrm{~N}\end{array}$ \\
\hline
\end{tabular}

Table 3.2 showing the chemicals used for the titration process

Results after collection and testing of the water samples and there parameters are shown in the table- 4 was obtaind based on the water qulity index calculation following the Indian Standard Drinking water Specifications IS10500:2012 and Bureau of Indian standards recommended input values are taken from the table- 5

\begin{tabular}{|c|c|c|c|c|c|c|c|}
\hline S.NO & $\mathrm{pH}$ & E.C & TDS & Turbidity & Colour & Odour & Taste \\
& & & Npm & Ntu & & \\
\hline 1 & 7.8 & 0.538 & 269 & 0.6 & Pale green & Earthy & Earthy \\
\hline 2 & 7.69 & 0.36 & 180 & 0 & Nil & No odour & No taste \\
\hline 3 & 7.74 & 1.608 & 804 & 0 & Nil & No odour & No taste \\
\hline 4 & 7.93 & 1.46 & 730 & 0 & Nil & No odour & Salt \\
\hline
\end{tabular}




\begin{tabular}{|c|c|c|c|c|c|c|c|}
\hline 5 & 7.77 & 0.884 & 442 & 1 & Nil & No odour & No taste \\
\hline 6 & 8.02 & 0.95 & 475 & 0 & Nil & No odour & No taste \\
\hline 7 & 8.6 & 0.384 & 192 & 6 & Pale green & Fishey & Earthy \\
\hline 8 & 7.0 & 0.064 & 32 & 1 & Nil & No odour & Sour \\
\hline 9 & 7.40 & 0.474 & 237 & 0 & Nil & No odour & No taste \\
\hline 10 & 7.96 & 0.44 & 220 & 1 & Nil & No odour & No taste \\
\hline
\end{tabular}

Table 4.0 concretion of parameter at the sampling points

\begin{tabular}{|c|c|c|c|c|c|c|c|c|}
\hline S.NO & Acidity & Alkality & DO & BOD & Chlorides & T.H & Mg2+ H & Ca2+ H \\
\hline 1 & 20 & 50 & 1.8 & 0.7 & 20.56 & 260 & 140 & 120 \\
\hline 2 & 21 & 75 & 2.5 & 1.4 & 167.37 & 1624 & 542 & 1082 \\
\hline 3 & 25 & 75 & 1.9 & 0.4 & 60.99 & 1544 & 1079 & 465 \\
\hline 4 & 29 & 100 & 1.6 & 1.3 & 41.33 & 748 & 528 & 220 \\
\hline 5 & 20 & 57.4 & 2.6 & 1.5 & 36.87 & 356 & 212 & 144 \\
\hline 6 & 10 & 75 & 1.9 & 1.6 & 36.87 & 352 & 176 & 176 \\
\hline 7 & 6 & 40 & 1.6 & 0.8 & 17.0 & 180 & 104 & 76 \\
\hline 8 & 5 & 37.5 & 2.4 & 1.4 & 3.4 & 20 & 20 & 0 \\
\hline 9 & 9 & 37.5 & 1.7 & 0.8 & 17.87 & 160 & 100 & 60 \\
\hline 10 & 5 & 30 & 2.8 & 1.7 & 21.55 & 168 & 64 & 104 \\
\hline
\end{tabular}

Table 4.1 concretion of parameter at the sampling points

\begin{tabular}{|l|l|l|l|l|}
\hline S.NO & PARAMETERS & $\begin{array}{l}\text { Maximum } \\
\text { values }\end{array}$ & $\begin{array}{l}\text { Minimum } \\
\text { values }\end{array}$ & Units \\
\hline 1 & $\mathrm{pH}$ & 8.8 & 6.5 & - \\
\hline 2 & Total alkalinity & 600 & 124 & $\mathrm{mg} / \mathrm{L}$ \\
\hline 3 & Total acidity & 16 & 8 & $\mathrm{mg} / \mathrm{L}$ \\
\hline 4 & DO & 8 & 4.6 & $\mathrm{mg} / \mathrm{L}$ \\
\hline 5 & $\begin{array}{l}\text { BOD }(3 \text { days } @ \\
\left.27^{\circ} \mathrm{C}\right)\end{array}$ & 2.0 & 0.2 & $\mathrm{mg} / \mathrm{L}$ \\
\hline
\end{tabular}




\begin{tabular}{|l|l|l|l|l|}
\hline 6 & COD & 44.5 & 11.9 & $\mathrm{mg} / \mathrm{L}$ \\
\hline 7 & TDS & 2000 & 500 & $\mathrm{mg} / \mathrm{L}$ \\
\hline 8 & TSS & 553 & 1631 & $\mathrm{mg} / \mathrm{L}$ \\
\hline 9 & Chloride & 1000 & 250 & $\mathrm{mg} / \mathrm{L}$ \\
\hline 10 & Total hardness & 600 & 200 & $\mathrm{mg} / \mathrm{L}$ \\
\hline 11 & Turbidity & 5 & 1 & $\mathrm{NTU}$ \\
\hline
\end{tabular}

Table-5 standard values with mean values

3.1pH in drinking water it is the indicator which is used to show the condition of the water weather it is soft are hard. By testing it by taking a $5 \mathrm{ml}$ of water in a test tube and placing 2 drops of universal indicator its shows the results of the $\mathrm{pH}$ with the colour comprasion with the table given on the bottle and also we can find by using digital meter. The $\mathrm{pH}$ value is fluctuated in between 7.0 to 8.6 which founded satisfactory according to the Indian standards

3.2 Turbidity it is the degree of the clear water and how much the light scatter by the sample. It can create the health issues by creating objectionable taste odour and colour along with interfering during disinfection. The standard value of turbidity according to the Indian standards is $5 \mathrm{NTU}$, the concentrations of the turbidity is found to be good in all the sample stations expect sample station 7 .

3.3 Total Dissolved Solids the TDS is measure with the help of the digital meter the total amount of inorganic salts with additional with the small amount organic matter soluble in the water, As this value is high the water become objectionable to drink and forms the scaling in the pipes and household appliances the max level considrable is $2000 \mathrm{mg} / \mathrm{L}$ according t o the Indian standards among the 10 samples all are found to be good.

3.4 Biological Oxygen Demand its is measured for determining the organic compounds present in the water. If the sample shows higher level BOD the sample is high polluted with presences of oxygen demand the marginal levels of the sample are good and some sample showing high valves of BOD

3.5 Hardness in the drinking water the hardness levels are in between $200 \mathrm{mg} / \mathrm{L}-600 \mathrm{mg} / \mathrm{L}$ according to the Indian standards we found sample station 2,3,4 are showing high values and remaining are in good condition .

Table:6 showing Water Quality Index

\begin{tabular}{|c|c|c|c|}
\hline $\begin{array}{c}\text { SAMPLING } \\
\text { STATIONS }\end{array}$ & WQI & WQI & WQI \\
\hline 1 & 22.10 & 16.74 & 25.79 \\
\hline 2 & 57.36 & 53.03 & 76.99 \\
\hline 3 & 60.90 & 49.68 & 80.63 \\
\hline 4 & 45.95 & 38.48 & 67.87 \\
\hline 5 & 35.38 & 25.82 & 53.86 \\
\hline 6 & 33.27 & 26.62 & 53.51 \\
\hline 7 & 32.17 & 27.74 & 50.88 \\
\hline 8 & 13.72 & 8.96 & 29.31 \\
\hline 9 & 18.53 & 13.00 & 34.86 \\
\hline 10 & 25.41 & 16.31 & 42.21 \\
\hline
\end{tabular}

Fig 3 Graph showing WQI 


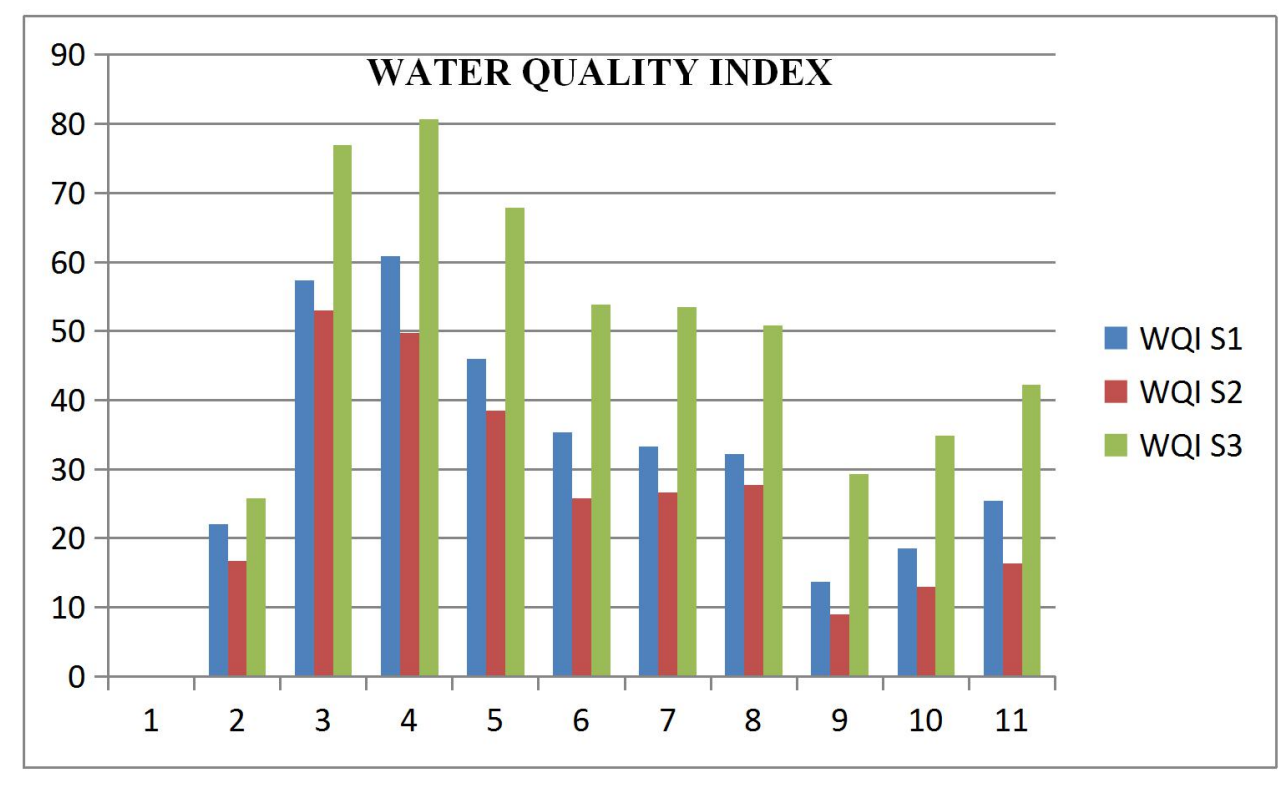

Table7 showing the NPI results of $\mathrm{pH}$

\begin{tabular}{|c|c|c|c|c|c|c|c|c|c|c|}
\hline $\begin{array}{c}\text { Item/para } \\
\text { meter }\end{array}$ & $\begin{array}{c}\text { Sample } \\
1\end{array}$ & $\begin{array}{c}\text { Sample } \\
2\end{array}$ & $\begin{array}{c}\text { Sample } \\
3\end{array}$ & $\begin{array}{c}\text { Sample } \\
4\end{array}$ & $\begin{array}{c}\text { Sample } \\
5\end{array}$ & $\begin{array}{c}\text { Sample } \\
6\end{array}$ & $\begin{array}{c}\text { Sample } \\
7\end{array}$ & $\begin{array}{c}\text { Sample } \\
8\end{array}$ & $\begin{array}{c}\text { Sample } \\
9\end{array}$ & $\begin{array}{c}\text { Sample } \\
10\end{array}$ \\
\hline Min & 7.8 & 7.21 & 6.98 & 7.54 & 7.2 & 7.09 & 7.92 & 6.99 & 7.2 & 7.41 \\
\hline Max & 6.87 & 7.69 & 7.56 & 7.93 & 7.77 & 8.02 & 8.6 & 7 & 7.4 & 7.96 \\
\hline Avg & 7.335 & 7.45 & 7.27 & 7.735 & 7.485 & 7.555 & 8.26 & 6.995 & 7.3 & 7.685 \\
\hline NPI & 0.8837 & 0.897 & 0.8759 & 0.9319 & 0.9018 & 0.9102 & 0.9951 & 0.8427 & 0.8795 & 0.9259 \\
\hline
\end{tabular}

Table 7.1 showing the NPI results of Total Dissolved Solids

\begin{tabular}{|c|c|c|c|c|c|c|c|c|c|c|}
\hline $\begin{array}{c}\text { Item/para } \\
\text { meter }\end{array}$ & $\begin{array}{c}\text { Sample } \\
1\end{array}$ & $\begin{array}{c}\text { Sample } \\
2\end{array}$ & $\begin{array}{c}\text { Sample } \\
3\end{array}$ & $\begin{array}{c}\text { Sample } \\
4\end{array}$ & $\begin{array}{c}\text { Sample } \\
5\end{array}$ & $\begin{array}{c}\text { Sample } \\
6\end{array}$ & $\begin{array}{c}\text { Sample } \\
7\end{array}$ & $\begin{array}{c}\text { Sample } \\
8\end{array}$ & $\begin{array}{c}\text { Sample } \\
9\end{array}$ & $\begin{array}{c}\text { Sample } \\
10\end{array}$ \\
\hline Min & 265 & 178 & 756 & 659 & 422 & 475 & 167 & 32 & 230 & 210 \\
\hline Max & 285 & 198 & 804 & 730 & 460 & 520 & 192 & 40 & 273 & 220 \\
\hline Avg & 275 & 188 & 780 & 694.5 & 441 & 497.5 & 179.5 & 36 & 251.5 & 215 \\
\hline NPI & $\begin{array}{c}0.2998 \\
91\end{array}$ & $\begin{array}{c}0.2050 \\
16\end{array}$ & 0.8506 & $\begin{array}{c}0.7573 \\
61\end{array}$ & $\begin{array}{c}0.4809 \\
16\end{array}$ & $\begin{array}{c}0.5425 \\
3\end{array}$ & $\begin{array}{c}0.1957 \\
47\end{array}$ & $\begin{array}{c}0.0392 \\
58\end{array}$ & $\begin{array}{c}0.2742 \\
64\end{array}$ & $\begin{array}{c}0.2344 \\
6\end{array}$ \\
\hline
\end{tabular}




\begin{tabular}{|c|c|c|c|c|c|c|c|c|c|c|}
\hline $\begin{array}{c}\text { Item/para } \\
\text { meter }\end{array}$ & $\begin{array}{c}\text { Sample } \\
1\end{array}$ & $\begin{array}{c}\text { Sample } \\
2\end{array}$ & $\begin{array}{c}\text { Sample } \\
3\end{array}$ & $\begin{array}{c}\text { Sample } \\
4\end{array}$ & $\begin{array}{c}\text { Sample } \\
5\end{array}$ & $\begin{array}{c}\text { Sample } \\
6\end{array}$ & $\begin{array}{c}\text { Sample } \\
7\end{array}$ & $\begin{array}{c}\text { Sample } \\
8\end{array}$ & $\begin{array}{c}\text { Sample } \\
9\end{array}$ & $\begin{array}{c}\text { Sample } \\
10\end{array}$ \\
\hline Min & 150 & 1122 & 565 & 385 & 189 & 204 & 96 & 3 & 60 & 114 \\
\hline Max & 120 & 1082 & 465 & 220 & 144 & 176 & 76 & 0 & 50 & 104 \\
\hline Avg & 135 & 1102 & 515 & 302.5 & 166.5 & 190 & 86 & 1.5 & 55 & 109 \\
\hline NPI & 0.4909 & 4.0072 & 1.8727 & 1.1 & 0.6054 & 0.6909 & 0.3127 & 0.0054 & 0.2 & 0.3963 \\
\hline
\end{tabular}

Table 7.3 showing the NPI results of Chlorides

\begin{tabular}{|c|c|c|c|c|c|c|c|c|c|c|}
\hline $\begin{array}{c}\text { Item/para } \\
\text { meter }\end{array}$ & $\begin{array}{c}\text { Sample } \\
1\end{array}$ & $\begin{array}{c}\text { Sample } \\
2\end{array}$ & $\begin{array}{c}\text { Sample } \\
3\end{array}$ & $\begin{array}{c}\text { Sample } \\
4\end{array}$ & $\begin{array}{c}\text { Sample } \\
5\end{array}$ & $\begin{array}{c}\text { Sample } \\
6\end{array}$ & $\begin{array}{c}\text { Sample } \\
7\end{array}$ & $\begin{array}{c}\text { Sample } \\
8\end{array}$ & $\begin{array}{c}\text { Sample } \\
9\end{array}$ & $\begin{array}{c}\text { Sample } \\
10\end{array}$ \\
\hline Min & 32.56 & 178.4 & 89.25 & 53.22 & 42.36 & 39.56 & 17 & 5.6 & 18.9 & 21.55 \\
\hline Max & 20.56 & 167.4 & 60.99 & 39.83 & 36.87 & 36.87 & 15 & 3.4 & 17.87 & 19.55 \\
\hline Avg & 26.56 & 172.9 & 75.12 & 46.525 & 39.615 & 38.215 & 16 & 4.5 & 18.385 & 20.55 \\
\hline NPI & 0.16 & 1.0415 & 0.4525 & 0.2802 & 0.2386 & 0.2302 & 0.0963 & 0.0271 & 0.1107 & 0.1237 \\
\hline
\end{tabular}

Table7.4 showing the NPI results of Dissolved Oxygen

\begin{tabular}{|c|c|c|c|c|c|c|c|c|c|c|}
\hline $\begin{array}{c}\text { Item/para } \\
\text { meter }\end{array}$ & $\begin{array}{c}\text { Sample } \\
1\end{array}$ & $\begin{array}{c}\text { Sample } \\
2\end{array}$ & $\begin{array}{c}\text { Sample } \\
3\end{array}$ & $\begin{array}{c}\text { Sample } \\
4\end{array}$ & $\begin{array}{c}\text { Sample } \\
5\end{array}$ & $\begin{array}{c}\text { Sample } \\
6\end{array}$ & $\begin{array}{c}\text { Sample } \\
7\end{array}$ & $\begin{array}{c}\text { Sample } \\
8\end{array}$ & $\begin{array}{c}\text { Sample } \\
9\end{array}$ & $\begin{array}{c}\text { Sample } \\
10\end{array}$ \\
\hline Min & 1.8 & 2.5 & 2.1 & 2.9 & 2.6 & 2.1 & 1.6 & 2.4 & 1.7 & 2.9 \\
\hline Max & 1.2 & 2.5 & 1.9 & 1.6 & 2.6 & 1.9 & 1.5 & 2 & 1.5 & 2.8 \\
\hline Avg & 1.5 & 2.5 & 2 & 2.25 & 2.6 & 2 & 1.55 & 2.2 & 1.6 & 2.85 \\
\hline NPI & $\begin{array}{c}0.2559 \\
73\end{array}$ & $\begin{array}{c}0.4266 \\
21\end{array}$ & $\begin{array}{c}0.3412 \\
97\end{array}$ & $\begin{array}{c}0.3839 \\
59\end{array}$ & $\begin{array}{c}0.4436 \\
86\end{array}$ & $\begin{array}{c}0.3412 \\
97\end{array}$ & $\begin{array}{c}0.2645 \\
05\end{array}$ & $\begin{array}{c}0.3754 \\
27\end{array}$ & $\begin{array}{c}0.2730 \\
38\end{array}$ & $\begin{array}{c}0.4863 \\
48\end{array}$ \\
\hline
\end{tabular}

Table7.5 showing the NPI results of Biological Oxygen Demand

\begin{tabular}{|l|l|l|l|l|l|l|l|l|l|l|}
\hline $\begin{array}{l}\text { Item/para } \\
\text { meter }\end{array}$ & $\begin{array}{l}\text { Sample } \\
1\end{array}$ & $\begin{array}{l}\text { Sample } \\
2\end{array}$ & $\begin{array}{l}\text { Sample } \\
3\end{array}$ & $\begin{array}{l}\text { Sample } \\
4\end{array}$ & $\begin{array}{l}\text { Sample } \\
5\end{array}$ & $\begin{array}{l}\text { Sample } \\
6\end{array}$ & $\begin{array}{l}\text { Sample } \\
7\end{array}$ & $\begin{array}{l}\text { Sample } \\
8\end{array}$ & $\begin{array}{l}\text { Sample } \\
9\end{array}$ & $\begin{array}{l}\text { Sample } \\
10\end{array}$ \\
\hline Min & 0.9 & 1.6 & 1 & 1.5 & 1.7 & 1.6 & 1 & 1.6 & 1.1 & 2 \\
\hline Max & 0.6 & 1.2 & 0.4 & 1.3 & 1.4 & 0.7 & 0.5 & 0.7 & 0.8 & 1.6 \\
\hline
\end{tabular}




\begin{tabular}{|l|l|l|l|l|l|l|l|l|l|l|} 
Avg & 0.75 & 1.4 & 0.7 & 1.4 & 1.55 & 1.15 & 0.75 & 1.15 & 0.95 & 1.8 \\
\hline NPI & 0.1875 & 0.35 & 0.175 & 0.35 & 0.3875 & 0.2875 & 0.1875 & 0.2875 & 0.2375 & 0.45 \\
\hline
\end{tabular}

Table 7.6 showing the NPI results of Turbidity

\begin{tabular}{|c|c|c|c|c|c|c|c|c|c|c|}
\hline $\begin{array}{c}\text { Item/para } \\
\text { meter }\end{array}$ & $\begin{array}{c}\text { Sample } \\
1\end{array}$ & $\begin{array}{c}\text { Sample } \\
2\end{array}$ & $\begin{array}{c}\text { Sample } \\
3\end{array}$ & $\begin{array}{c}\text { Sample } \\
4\end{array}$ & $\begin{array}{c}\text { Sample } \\
5\end{array}$ & $\begin{array}{c}\text { Sample } \\
6\end{array}$ & $\begin{array}{c}\text { Sample } \\
7\end{array}$ & $\begin{array}{c}\text { Sample } \\
8\end{array}$ & $\begin{array}{c}\text { Sample } \\
9\end{array}$ & $\begin{array}{c}\text { Sample } \\
10\end{array}$ \\
\hline Min & 0.7 & 0 & 0 & 0 & 1 & 0 & 16 & 1 & 0 & 1 \\
\hline Max & 0.6 & 0 & 0 & 0 & 0.9 & 0 & 12 & 1 & 0 & 1 \\
\hline Avg & 0.65 & 0 & 0 & 0 & 0.95 & 0 & 14 & 1 & 0 & 1 \\
\hline NPI & 0.0755 & 0 & 0 & 0 & 0.1104 & 0 & 1.6279 & 0.1162 & 0 & 0.1162 \\
\hline
\end{tabular}

Table 7.7 showing the NPI results of Acidity

\begin{tabular}{|c|c|c|c|c|c|c|c|c|c|c|}
\hline $\begin{array}{c}\text { Item/para } \\
\text { meter }\end{array}$ & $\begin{array}{c}\text { Sample } \\
1\end{array}$ & $\begin{array}{c}\text { Sample } \\
2\end{array}$ & $\begin{array}{c}\text { Sample } \\
3\end{array}$ & $\begin{array}{c}\text { Sample } \\
4\end{array}$ & $\begin{array}{c}\text { Sample } \\
5\end{array}$ & $\begin{array}{c}\text { Sample } \\
6\end{array}$ & $\begin{array}{c}\text { Sample } \\
7\end{array}$ & $\begin{array}{c}\text { Sample } \\
8\end{array}$ & $\begin{array}{c}\text { Sample } \\
9\end{array}$ & $\begin{array}{c}\text { Sample } \\
10\end{array}$ \\
\hline Min & 23 & 26 & 32 & 29 & 30 & 13 & 9 & 5 & 19 & 10 \\
\hline Max & 20 & 21 & 25 & 26 & 20 & 9 & 4 & 3 & 9 & 5 \\
\hline Avg & 21.5 & 23.5 & 28.5 & 27.5 & 25 & 11 & 6.5 & 4 & 14 & 7.5 \\
\hline NPI & $\begin{array}{c}1.9545 \\
45\end{array}$ & $\begin{array}{c}2.1363 \\
64\end{array}$ & $\begin{array}{c}2.5909 \\
09\end{array}$ & 2.5 & $\begin{array}{c}2.2727 \\
27\end{array}$ & 1 & $\begin{array}{c}0.5909 \\
09\end{array}$ & $\begin{array}{c}0.3636 \\
36\end{array}$ & $\begin{array}{c}1.2727 \\
27\end{array}$ & $\begin{array}{c}0.6818 \\
18\end{array}$ \\
\hline
\end{tabular}

Table7.8 showing the NPI results of Alkalinity

\begin{tabular}{|l|l|l|l|l|l|l|l|l|l|l|}
\hline $\begin{array}{l}\text { Item/para } \\
\text { meter }\end{array}$ & $\begin{array}{l}\text { Sample } \\
1\end{array}$ & $\begin{array}{l}\text { Sample } \\
2\end{array}$ & $\begin{array}{l}\text { Sample } \\
3\end{array}$ & $\begin{array}{l}\text { Sample } \\
4\end{array}$ & $\begin{array}{l}\text { Sample } \\
5\end{array}$ & $\begin{array}{l}\text { Sample } \\
6\end{array}$ & $\begin{array}{l}\text { Sample } \\
7\end{array}$ & $\begin{array}{l}\text { Sample } \\
8\end{array}$ & $\begin{array}{l}\text { Sample } \\
9\end{array}$ & $\begin{array}{l}\text { Sample } \\
10\end{array}$ \\
\hline Min & 61 & 90.2 & 87.3 & 111 & 68.2 & 79 & 50 & 39.5 & 37.5 & 45 \\
\hline Max & 50 & 75 & 75 & 100 & 57.4 & 75 & 40 & 37.5 & 29.5 & 30 \\
\hline Avg & 55.5 & 82.6 & 81.15 & 105.5 & 62.8 & 77 & 45 & 38.5 & 33.5 & 37.5 \\
\hline NPI & $\begin{array}{l}0.3801 \\
37\end{array}$ & $\begin{array}{l}0.5657 \\
53\end{array}$ & $\begin{array}{l}0.5558 \\
22\end{array}$ & $\begin{array}{l}0.7226 \\
03\end{array}$ & $\begin{array}{l}0.4301 \\
37\end{array}$ & $\begin{array}{l}0.5273 \\
97\end{array}$ & $\begin{array}{l}0.3082 \\
19\end{array}$ & $\begin{array}{l}0.2636 \\
99\end{array}$ & $\begin{array}{l}0.2294 \\
52\end{array}$ & $\begin{array}{l}0.2568 \\
49\end{array}$ \\
\hline
\end{tabular}




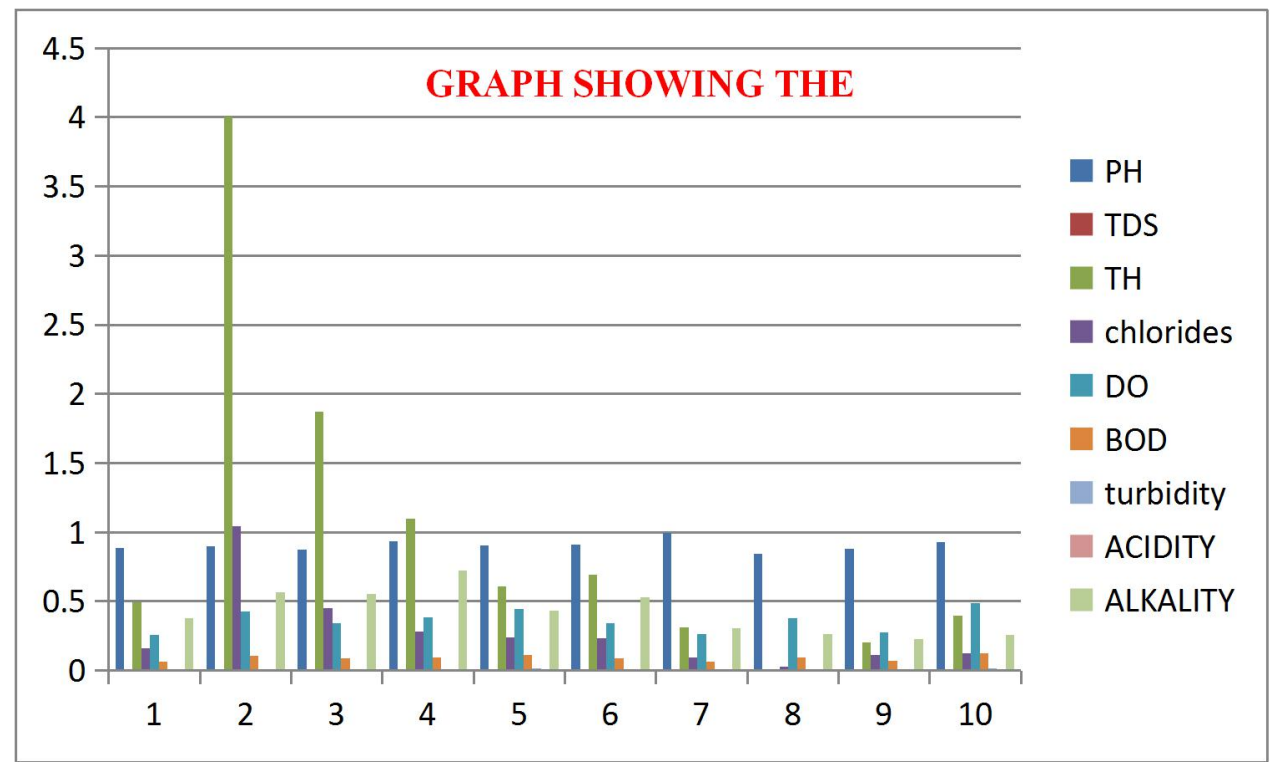

Table 8 showing WQI RESULTS

\begin{tabular}{|c|c|c|}
\hline S.NO & SAMPLE STATION & $\begin{array}{c}\text { WATER } \\
\text { QUALITY } \\
\text { INDEX }\end{array}$ \\
\hline 1 & YERRABALAM & Excellent \\
\hline 2 & KRISHANAYAPALEM & FAIR \\
\hline 3 & MANDADAM & FAIR \\
\hline 4 & VELAGAPUDI & GOOD \\
\hline 5 & RAYAPUDI & GOOD \\
\hline 6 & THULLUR & GOOD \\
\hline 7 & AMARAVATHI & GOOD \\
\hline 8 & SRM UNVERSITY & Excellent \\
\hline 9 & LINGAYA PALEM & Excellent \\
\hline 10 & DONDAPADU & GOOD \\
\hline
\end{tabular}

Table9 Showing NPI Results

\begin{tabular}{|c|c|c|}
\hline S.NO & SAMPLE STATION & $\begin{array}{c}\text { Nemerow'S Pollution } \\
\text { Index (NPI) }\end{array}$ \\
\hline 1 & YERRABALAM & Excellent \\
\hline 2 & KRISHANAYAPALEM & $\begin{array}{c}\text { Total hardness and chlorides levels } \\
\text { are high }\end{array}$ \\
\hline 3 & MANDADAM & Total hardness levels are high \\
\hline 4 & VELAGAPUDI & Total hardness levels are high \\
\hline
\end{tabular}




\begin{tabular}{|c|c|c|}
\hline 5 & RAYAPUDI & Excellent \\
\hline 6 & THULLUR & Excellent \\
\hline 7 & AMARAVATHI & Excellent \\
\hline 8 & SRM UNVERSITY & Excellent \\
\hline 9 & LINGAYA PALEM & Excellent \\
\hline 10 & DONDAPADU & Excellent \\
\hline
\end{tabular}

\section{CONCLUSION}

As per the Nemerow's Pollution Index (NPI) It conclude that the SS2,SS3,SS4 are showing high values of calcium and magnesium hardness. As well as SS2 is also having moderate raise in chlorides concentration As per the water quality index method (WQI) The SS1,SS8,SS9 are prefect which does not required any further treatment And the SS4,SS5,SS6,SS10 are proved in the good region slightly treatment is required such as boiling of water is enough to remove the impurities in the water.The remaining sample stations 2 and SS3 are in fair condition this shows the water may need some treatment.to remove the impurities such as the hardness in the water.

\section{REFERENCES}

1. Sandhya (2005) assessed portability of the groundwater in various localities in Bollaram area Journal of Chemical and Pharmaceutical Sciences ISSN: 0974-2115 https://www.jchps.com/specialissues/2016\%20SPECIAL\%20ISSUE\%2010/09\%20JCP

2. Ravi Chandra Babu, (2006) evaluated groundwater pollution potential in Bakkannapllem, Madhurwada and Vijayawada. Civil and Environmental Research ISSN 2224-5790 (Print) ISSN 2225-0514

3. RadhaMadhavi(2006) attempted to assess the quality of water both surface and sub-surface along Bandar cana

4. Mehmet celik,metia tastekin ,kamllkayaball(2007) studied manak solid waste disposal site covers an area of approximately 0.5 square kilometre and the amount of waste it holds is around $13 \times 106 \mathrm{~m} 3$, the amount of lechate measured through a weir at the toe of the body of waste is 164,000 me per annum

5. C. R. Ramnkrishnniah, C. Sadashlvalah (2009) and G.Ranganna Is aimed at assessing the water quality index (WQI) for the groundwater of Tumkurtaluk, This lots been determined by collecting groundwater samples and subjecting the samples to a comprehensive physico chemical analysis. For calculating the WQI, the following 12 parameters have been considered https://www.researchgate.net/publication/237619743_Assessment_of_Water_Quality_Index_for_the_Grou ndwater_in_Tumkur_Taluk_Karnataka_State_India

6. Usharani K.Umaranl K.Ayynsamy.P.M. Shanthl, K. Lakshmanaperumalsamy P.(2010) studied, the physicchemical and bacteriological characteristics of Noyyal River and groundwater quality of Perur, India JASEM ISSN 1119-8362

www.bioline.org.br/ja

7. N Raj Kumar, T.Subramani, L.Elango, International journal of environmental science Volume 1, nol,2010 https://scholar.google.co.in/citations?user=1aqlwtgAAAAJ\&hl=en

8. G. SrinivasRao, G. Nagcswararao (2013) have identified fifty sampling stations and water samples were collected from June to May 2008, to know the groundwater quality of Greater Visakhapatnam city using Water Quality Index ARCH.ENVIRON.SCI.(2013),7,1-5 https://aes.asia.edu.tw/Issues/AES2013/RaoGS2013

9. P.Vasauthi, R.Srinivasarap, havan, P.Prasad(2013) assessed the level of groundwater contamination around a solid waste disposal site in Chennai, India. Estimated the contaminant concentration around the solid waste disposal site 
10. G. Venkatesan, G. Swaminathan, R. Nagarajan (2013)evaluated the groundwater chemical quality changes adjacent to solid waste disposal area of Tiruchirappalli metropolitan area was by collected groundwater samples from three bore wells in the vicinity.International Journal of Environmental Engineering 2013 Vol.5 No.2

https://www.inderscience.com/info/inarticle.php?artid=52906

11. G. SrinivasRao, G. Nageswararao "Assessment of Groundwater quality using Water Quality Index" ARCH. ENVIRON. SCl. (2013)

https://pdfs.semanticscholar.org/956c/76944244a99e3290eb55570c83b385d93b73.pdf

12. Hydrogeochemical Analysis and Evaluation of Groundwater Quality in Bardhaman District, West Bengal, India

https://www.researchgate.net/publication/306360523_Hydrogeochemical_Analysis_and_Evaluation_of_Gro undwater_Quality_in_Bardhaman_District_West_Bengal_India

13. Evaluation of Water Quality Index for Drinking Water

14. Assessment of Water Quality of Singanamala Tank (Sri Rangarayalu Cheruvu), Singanamala, Anantapuramu District, Andhra Pradesh, India Kolala Venkatararamanaiah1, V N Jayaram Naik2 ,G.H.Philip3(Department of Zoology, Sri Krishnadevaraya University, Anantapuramu, Andhra Pradesh, India)Corresponding Author: G H $P$

15. Bureau of Indian Standards (BIS) for drinking Water Specification IS: 10500, BIS, New Delhi, India, 2012

16. K.Venkataramanaiah, V.N. Jayaram Naik and G.H. Philip (2017,IOSR - JESTFT) assessment of water quality of singanamala district, AP, India https://www.iosrjournals.org/iosr-jestft/papers/vol11-issue\%2010/Version2/F1110024452.pdf

17. V Ramakrishna, M charitha, G.V.S.N sai Asian pacific journal of research impact factor:6.58. https://apjor.com/splissue/06042018Full\%20text.pdf

18. Indian standards codes 